\title{
Synthesis of Some New 1,2,4-Triazoles Derived from 2-Mercaptobenzimidazole
}

\author{
Zainab, A.K. Al-Messri *
}

Date of acceptance $3 / 8 / 2008$

\begin{abstract}
:
New 1,2,4-triazole derivatives of 2-mercaptobenzimidazole (MB) are reported. Ethyl (benzimidazole-2-yl thio) acetate (1) has been prepared by condensing 2mercaptobenzimidazole with ethylchloroacetate. The ester (1) on reacting with hydrazine hydrate gave the corresponding acetohydrazide(2)which was reacted separately with phenylisocyanate and phenylisothiocyanate, followed by ring closure in an alkaline medium giving 3-[(benzimidazole-2-yl thio) methyl]-4-phenyl-1,2,4triazole-5-ol and 3-[(benzimidazole-2-yl thio) methyl]-4-phenyl-1,2,4-triazole-5-thiol respectively (6,7). Reaction of acetohydrazide (2) with $\mathrm{CS}_{2}$ and ethanol/KOH, gave dithiocarbazate salt (8). Cyclization of (8) with hydrazine hydrate gave 3-[(benzimidazole-2-yl thio) methyl]-4-amino-1,2,4-triazole-5-thiol (9).

Furthermore, new Schiff bases (3a-e) were prepared through the reaction of the acetohydrazide (2) with aromatic aldehydres. The prepared compounds were identified by spectral methods FTIR, UV. Measurements of some physical properties and some specific reactions, were carried out

\section{Introduction}

Benzimidazole nucleus play an important role in antimicrobial activity. Number of benzimidazole derivatives were synthesized and evaluated as antifungal, antibacterial[1-4], and as potent anti-HIV agents[5]. In industry, 2-mercaptobenzimid-azole is used as antioxidant in the manufacture of industrial rubber[6].

Furthermore, the 1,2,4-triazole compounds are considered as interesting five membered heterocycles since possess important pharmacological activities such as fungicidal, insecticidal, antimicrobial agents and anti-inflammatory[7-8] also as plant growth regulating[9]. Keeping these facts in view, we have synthesized new
\end{abstract}

* Department of Chemistry, College of Science, University of Baghdad, Iraq 
1,2,4-triazole derivatives of 2-mercaptobenzimidazole (6, 7 and 9) and new Schiff bases (3a-e).

\section{Materials and Methods:}

Melting points were determined on Gallenkamp melting point apparatus and are uncorrected.

FTIR spectra were recorded on $\begin{array}{lll}\text { Shimadzu } & \text { FTIR } & 8400\end{array}$ spectrophotometer as $\mathrm{KBr}$ disc.

U.V spectra were recorded on Shimadzu UV-VIS recorder.

Starting chemical compounds were obtained from Fluka or Aldrich. And the physical properties of the products are listed in table (1).

\section{Preparation of Ethyl(benzimidazole-} 2-yl thio) acetate [1]

Ethyle chloroacetate $(10.6 \mathrm{~mL}$, $0.1 \mathrm{~mol}$ ), was added dropwise to a stirred solution of 2mercaptobenzimidazole $(15 \mathrm{~g}, 0.1 \mathrm{~mol})$, and anhydrous potassium carbonate $(13.8 \mathrm{~g}, 0.1 \mathrm{~mol})$ in absolute ethanol $(100 \mathrm{~mL})$. The reaction mixture was refluxed for $6 \mathrm{hrs}$. filtered and the solvent was evaporated. The crude product was recrystallized from ethanol to give a white crystals of the ester [1]

\section{Preparation of (Benzimidiazole-2-yl} thio) acetohydrazide [2]

A mixture of ester [1] (11.8g, $0.05 \mathrm{~mol}$ ) and excess $98 \%$ hydrazine hydrate $(10 \mathrm{~mL}, 0.2 \mathrm{~mol})$ were refluxed for $4 \mathrm{hrs}$. The reaction mixture was poured in to ice water. The separated precipitate was filtered and recrystallized from ethanol to give a white crystals of the hydrazide [2].

\section{Schiff Base Derivatives of}

(Benzimid- azole- 2- yl thio) acetohydrazide [3a-e]

To a hot stirred solution of the hydrazide [2] $(0.22 \mathrm{~g}, 0.001 \mathrm{~mol})$ in methanol $(5 \mathrm{~mL})$, appropriate aromatic aldehyde $(0.001 \mathrm{~mol})$ was added. The reaction mixture was heated to $70^{\circ} \mathrm{C}$ for (1-3 hrs.). The separated solid was filtered and recrystallized from ethanol.

\section{1-[Benzimidazole-2-yl thio) methyl} carbonyl]-4-phenyl semicarbazide or thiosemicarbazide $[4,5]$

Ethanolic solution of the hydrazide [2] $(2.2 \mathrm{~g}, 0.01 \mathrm{~mol})$ and phenyl isocyanate $(1.08 \mathrm{~mL}, 0.01 \mathrm{~mol})$ or phenyl isothiocyanate $(1.2 \mathrm{~mL}$, $0.01 \mathrm{~mol}$ ) was stirred at room temperature overnight. The precipitate 
was filtered, washed with ethanol, to get compounds $[4,5]$ respectively.

\section{3-[(Benzimidazole-2-yl thio) methyl]-} 4-phenyl-1,2,4-triazole-5-ol or -5thiol $[6,7]$

The semicarbazide [4] (3.4g, $0.01 \mathrm{~mol}$ ) or thiosemicarbazide [5] $(3.57 \mathrm{~g}, 0.01 \mathrm{~mol})$ was refluxed in $10 \%$ sodium hydroxide solution $(25 \mathrm{~mL})$ for 6 hrs., cooled, poured onto ice water, stirred and filtered, to gave [6,7] compounds.

\section{Potassium-3-[(benzimidazole-2-yl}

thio) methyl] dithiocarbazate [8]

To a stirred ethanolic solution of $\mathrm{KOH}(1.68 \mathrm{~g}, 0.03 \mathrm{~mol})$ in $(20 \mathrm{~mL})$, hydrazide [2] $(2.2 \mathrm{~g}, 0.01 \mathrm{~mol})$ then $\mathrm{CS}_{2}$ $(1.8 \mathrm{~mL}, 0.03 \mathrm{~mol})$ were added slowly. The reaction mixture was stirred overnight. Dry ether $(20 \mathrm{~mL})$ was added and the yellow ppt. was filtered, washed with ether and vacuum dried. The salt [8] was obtained in almost quantitative yield and was employed in the next step without further purification.

3-[(Benzimidazde-2-yl thio) methyl]4-amino-1,2,4-triazole-5-thiol [9]

A suspension of potassium salt [8] $(0.01 \mathrm{~mol})$ in excess hydrazine hydrate $(5 \mathrm{~mL})$ was refluxed until the evolution of $\mathrm{H}_{2} \mathrm{~S}$ was ceased; during reflux the colour of the reaction mixture changed to green and a homogenous solution resulted. After cooling, the reaction mixture was acidified with $10 \% \mathrm{HCl}$ to yield a white precipitate. Physical properties are listed in Table(1).

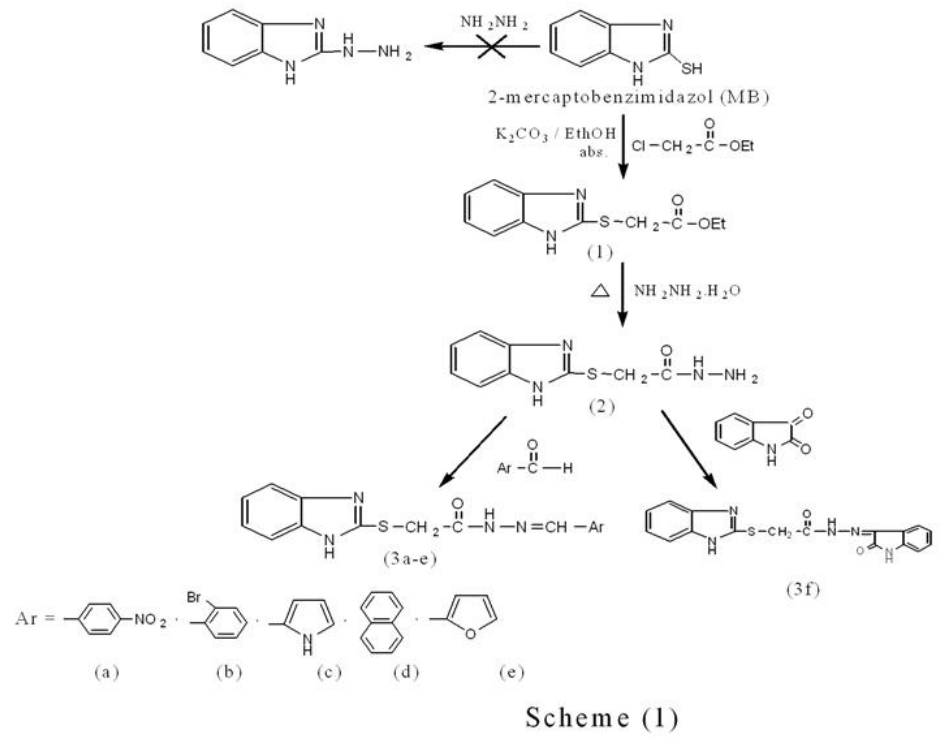




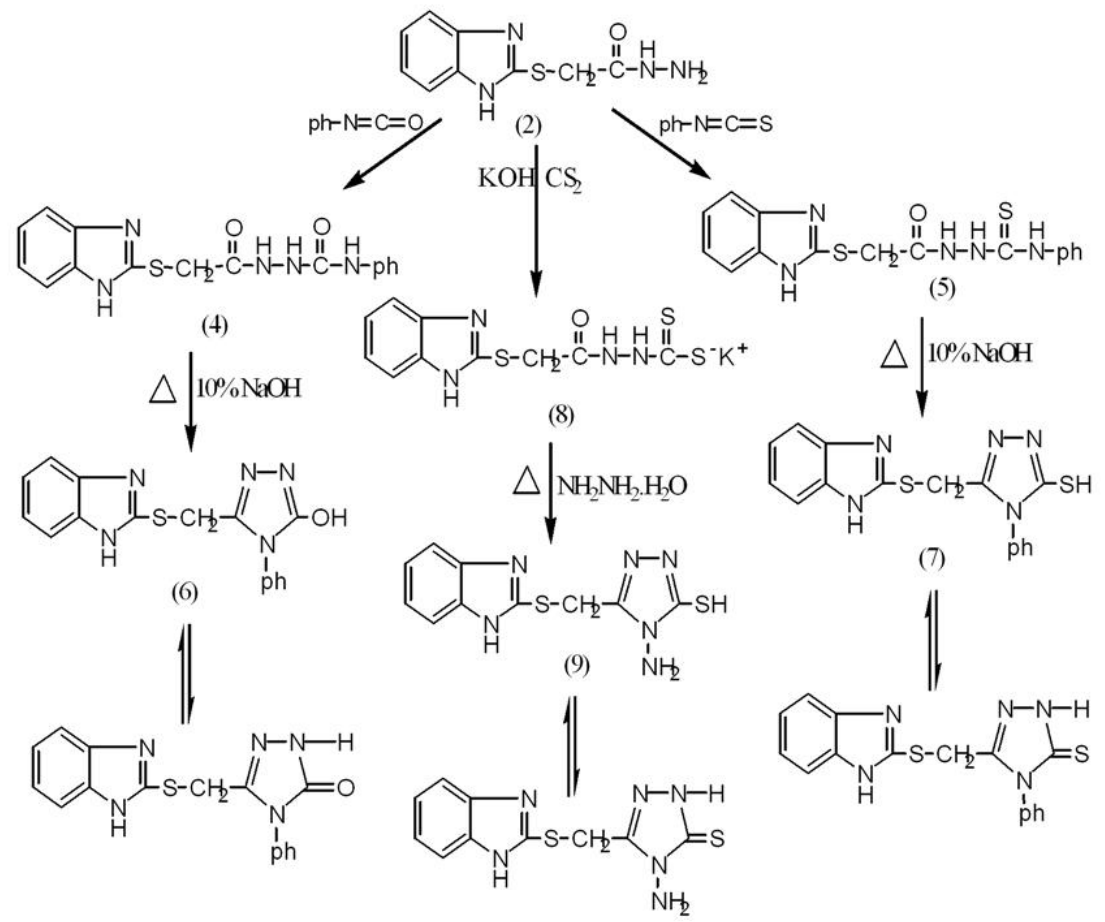

Scheme (2)

Table (1): Physical properties of the prepared compounds

\begin{tabular}{|c|c|c|c|c|c|c|}
\hline \begin{tabular}{|c|} 
Comp. \\
no.
\end{tabular} & \begin{tabular}{|c|} 
Molecular \\
Formula
\end{tabular} & Comp. Structure & m.p. ${ }^{\circ} \mathrm{C}$ & $\begin{array}{c}\text { Yield } \\
\%\end{array}$ & Colour & $\begin{array}{l}\text { Recryst. } \\
\text { solvents }\end{array}$ \\
\hline 1 & $\mathrm{C}_{11} \mathrm{H}_{12} \mathrm{~N}_{2} \mathrm{O}_{2} \mathrm{~S}$ & & 100 & 88 & White & Ethanol \\
\hline 2 & $\mathrm{C}_{9} \mathrm{H}_{10} \mathrm{~N}_{4} \mathrm{OS}$ & & 230 & 68 & White & Ethanol/water \\
\hline 3 & $\mathrm{C}_{10} \mathrm{H}_{9} \mathrm{~N}_{4} \mathrm{OSAr}$ & & & & & \\
\hline $3 a$ & $\mathrm{C}_{16} \mathrm{H}_{13} \mathrm{~N}_{5} \mathrm{O}_{3} \mathrm{~S}$ & & \begin{tabular}{|l|}
$288-290$ \\
\end{tabular} & 85 & Red & Methanol \\
\hline $3 b$ & $\mathrm{C}_{16} \mathrm{H}_{13} \mathrm{~N}_{4} \mathrm{OSBr}$ & & $245-250$ & 46 & Pale yellow & Methanol \\
\hline $3 \mathrm{c}$ & $\mathrm{C}_{14} \mathrm{H}_{13} \mathrm{~N}_{5} \mathrm{OS}$ & & $145-148$ & 79 & Deep violete & Methanol \\
\hline
\end{tabular}




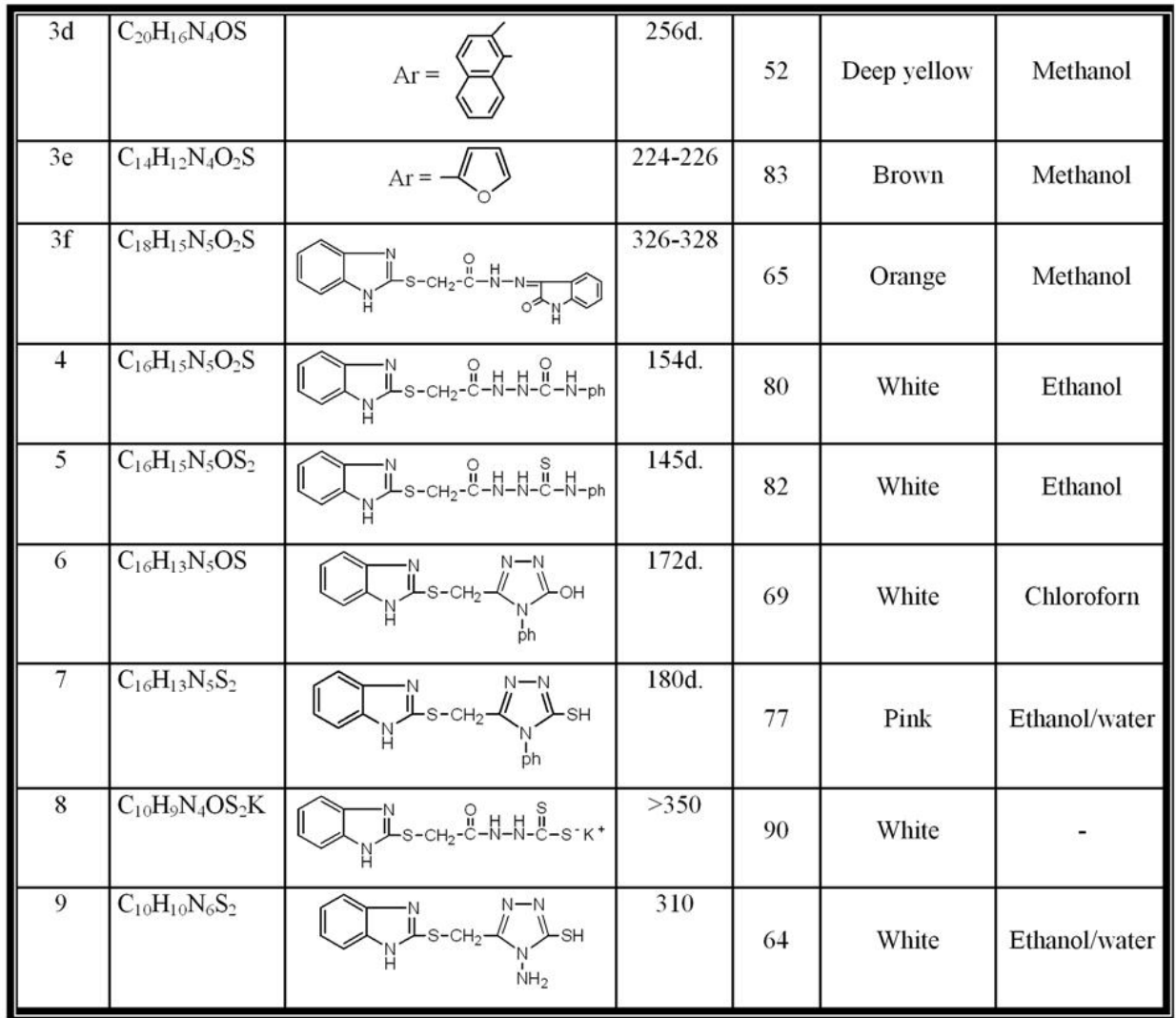

\section{Results and Discussion}

In the present work the synthesis of some new 1,2,4-triazoles and Schiff base derivatives were achieved from 2 mercaptobenzimidazole, the synthetic route used is shown in schemes ( 1 and 2).

Ethyl(benzimidazole - 2 - yl thio) acetate [1] was prepared by condensing 2 - mercaptobenzimidazole with ethylchloro acetate. The FTIR spectrum indicated the presence of a $v \mathrm{C}=\mathrm{O}$ ester $\left(1743 \mathrm{~cm}^{-1}\right)$ and $v \mathrm{~S}-\mathrm{CH}_{2}$ $\left(1683 \mathrm{~cm}^{-1}\right)[10]$, also hydroxamic acid test improved the presence of ester group. The UV spectrum show a band at $\lambda_{\max }(287 \mathrm{~nm})$, improving that the reaction was carried on the $\mathrm{S}$ not on $\mathrm{N}$ in the 2-mercaptobenzimidazole ring[11].

The ester [1] through reaction with hydrazine hydrate, gave (benzimidazole-2-yl thio) acetohydrazide [2]. FTIR spectrum showed a shift in the $\mathrm{vC}=\mathrm{O}$ band from $\left(1743 \mathrm{~cm}^{-1}\right)$ to $\left(1666 \mathrm{~cm}^{-1}\right)$ amide I. Absorption at $(3317,3278$ and 3155 $\mathrm{cm}^{-1}$ ) could be attributed to $-\mathrm{NH}_{2}$ group asym. and sym., and $-\mathrm{NH}$ group stretching band respectively.

The Schiff bases (3a-f) were obtained in good yield through the reaction of hydrazide [2] with different aromatic aldehydes (scheme 1). The 
structured of all the synthesized compounds were confirmed by FTIR and UN spectral. UV spectrums of the Schiff bases (3a-f) show a shift of band to higher $\lambda_{\max }$ (red shift) because of the chromophore groups on aromatic ring. The characteristic absorption bands are listed in (Table 2) and the FTIR spectra of (3f) is shown in Figure (1)

The hydrazide [2] was converted to semicarbazide [4] and thiosemicarbazide [5] by the reaction with phenylisocyanate or phenylisothiocyanate at room temperature (scheme 2). FTIR spectral data showed absorption at $\left(1695 \mathrm{~cm}^{-1}\right)$ $v \mathrm{C}=\mathrm{O}$ in semicarbazide [4] and (1234 $\left.\mathrm{cm}^{-1}\right) v \mathrm{C}=\mathrm{S}$ in thiosemicarbazide [5], also showed the out-of-plane $\mathrm{C}-\mathrm{H}$ bending at $\sim 750$ and $690 \mathrm{~cm}^{-1}$.

Treatment of compounds [4] and [5] with $10 \%$ sodium hydroxide solution afford intramolecular cyclization to give the 3[(benzimidazole-2-yl thio)]-4-phenyl1,2,4-triazole-5-ol [6] and 3[(benzimidazole-2-yl thio)methyl]-4phenyl-1,2,4-triazole-5-thiol respectively. The structures of hydroxyl-triazole [6] and thio-triazole [7] were identified from FTIR and UV. The FTIR spectrum of [6] showed $v O$ -
$\mathrm{H}$ vibration at $\left(3448 \mathrm{~cm}^{-1}\right)$ broad and $v \mathrm{C}=\mathrm{N}$ at $\left(1596 \mathrm{~cm}^{-1}\right)$. FTIR spectrum of [7] (Figure 2) showed $v \mathrm{~N}-\mathrm{H}$ vibration at $\left(3232 \mathrm{~cm}^{-1}\right), \quad v \mathrm{C}=\mathrm{N}$ band at $(1627$ $\left.\mathrm{cm}^{-1}\right), v \mathrm{C}=\mathrm{S}$ at $\left(1180 \mathrm{~cm}^{-1}\right)$ and out-ofplane $\mathrm{C}-\mathrm{H}$ bending at $(748$ and 649 $\mathrm{cm}^{-1}$ ).

On the other hand, Hoggarth's method[12] has been used for the preparation of 3-[(benzimidazole-2-yl thio)methyl]-4-amino-1,2,4-triazole-5thiol [9] by reaction of hydrazide [2] with $\mathrm{CS}_{2}$ in ethanolic $\mathrm{KOH}$ gave the dithiocarbazate salt [8] in excellent yield, which, was then cyclized by refluxing with $98 \%$ hydrazine hydrate to give a moderate yield of triazole derivative[9] [13]. FTIR spectrum (Figure 3) showed absorptions at (3286$3163 \mathrm{~cm}^{-1}$ ) asym. and sym. for $-\mathrm{NH}_{2}$ group which overlap with absorption $\mathrm{N}$ $\mathrm{H}$ group, and $\left(1203 \mathrm{~cm}^{-1}\right)$ for $\mathrm{C}=\mathrm{S}$ due to thio-thion structure formation[14].

Several attempts have been carried out to prepare 2hydrazinobenzimidazole by the reaction of 2-mercaptobenzimidazole with $98 \%$ hydrazine hydrate, but all attempts have been failed and no achievements were obtained by this way[15]

Table (2): UV and FTIR absorption spectra data of the prepared compounds

\begin{tabular}{|c|c|c|c|c|c|c|c|c|c|}
\hline \multirow[b]{2}{*}{$\begin{array}{c}\text { Comp. } \\
\text { no. }\end{array}$} & \multirow[b]{2}{*}{ Comp. structure } & \multirow{2}{*}{\begin{tabular}{|c}
$\mathrm{UV}$, \\
$(\mathbf{E t O H})$ \\
$\lambda_{\max }$ \\
$(\mathrm{nm})$
\end{tabular}} & \multicolumn{7}{|c|}{ FTIR $\left(\mathrm{cm}^{-1}\right)$} \\
\hline & & & $v \mathbf{N}-\mathrm{H}$ & $\begin{array}{c}v \mathrm{C}-\mathrm{H} \\
\text { aromatic }\end{array}$ & $\mid \begin{array}{c}v \mathbf{C}-\mathbf{H} \\
\text { aliphatic }\end{array}$ & $v \mathbf{C}=\mathbf{O}$ & $\begin{array}{c}v \mathbf{C}=\mathrm{C} \\
\& \\
v \mathbf{C}=\mathrm{N}\end{array}$ & \begin{tabular}{|c} 
O-O- \\
$\mathbf{P}$ \\
$\delta \mathrm{C}-\mathrm{H}$
\end{tabular} & $\begin{array}{l}\text { Other } \\
\text { bands }\end{array}$ \\
\hline 1 & & 257 & 3139 & 3016 & $\begin{array}{l}2970, \\
2877\end{array}$ & 1743 & $\begin{array}{l}1620, \\
1581\end{array}$ & 748 & $\mathrm{~S}-\mathrm{CH}_{2} 2638$ \\
\hline
\end{tabular}




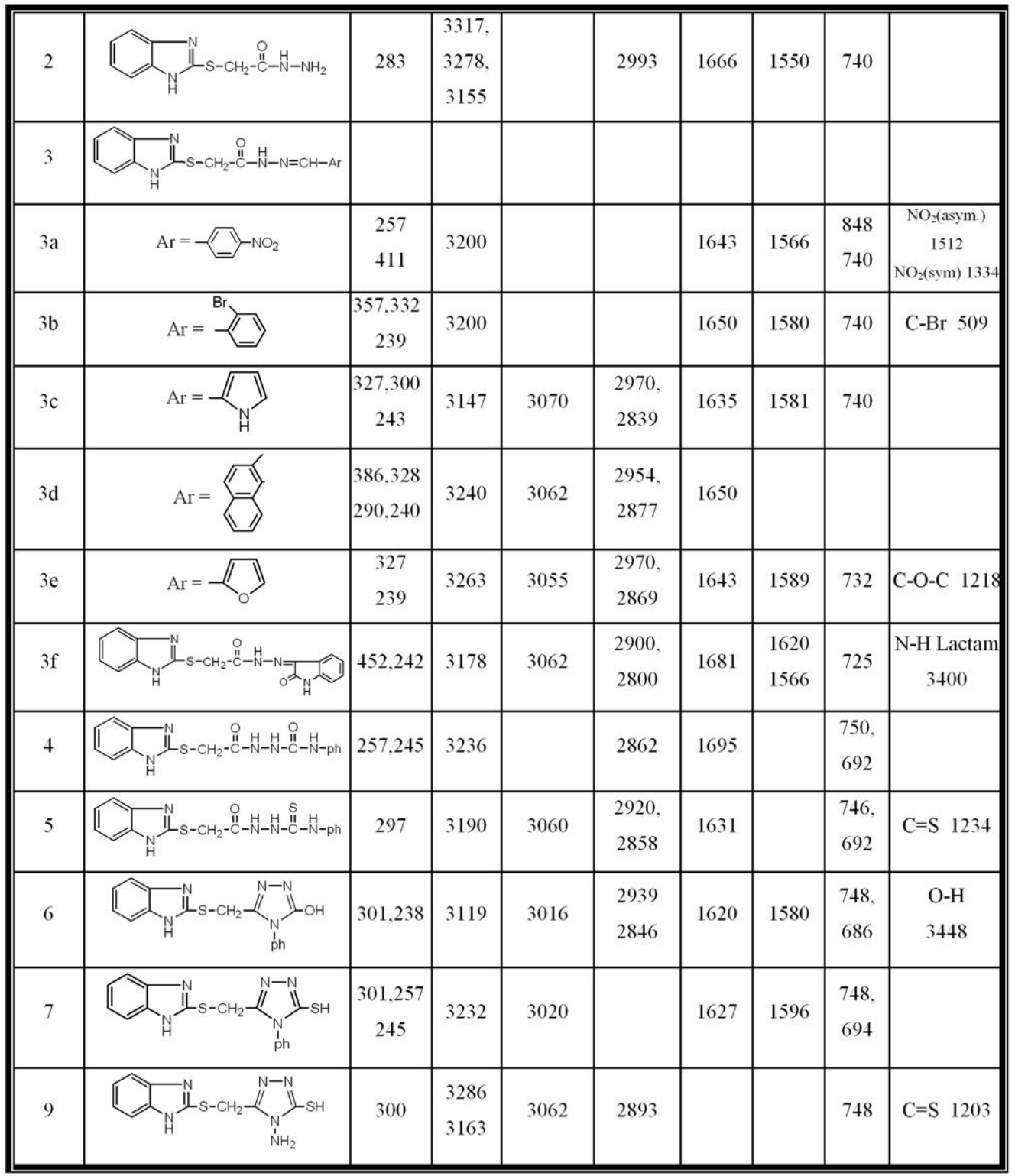

\section{References}

1. Vidiallac, C., Guillon, J., Arpin, C. and Forbar-Baresu, I., (2007). Synthesis of Operazole analogues and evalution of these as potential inhibitors of the multidrug Efflux Pump Nor A of Staphylococcus aureus. Antimicrobial Agents Chemotherapy. 51:831-838. 
2. DeAlmeida, M.V., Cardoso, S.H., DeAssis, J.V., and DeSouza, M.V.N. (2007) Synthesis of 2mercaptobenzothiazole and 2mercaptobenzimidazole

derivatives condensed with carbohydrates as potential antimicrobial agents. Journal of Sulfur Chemistry. 28:17-22.

3. Gokce, M., Utku, S., Bercin, E., E., Ozcelik, B., Karaoglu, T. and Noyanalpan, N. (2005). Synthesis and in vitro antimicrobial and cytotoxcity activites of 2-[(2-nitro-1-phenyl alkyl) thio]benzoic acid derivatives. Turk. J. Chem. 29:207-217.

4. Kuhler, T.C., Swanson, M., Christenson, B., Klintenoerg, C.A., Lamin,, B., Fagerhag, J. and Roberto, G. (2002). J. Med. Chem. 45:4282-4299.

5. Rao, A., Chimirri, A., Ferro, S., Monforte, A., Monfort, P. and Zappala, M. (2004). Microwave-assisted synthesis of benzimidazole and thiazolidinone derivatives as HIV-IRT inhibitors. ARKIVOC. (V): 147-155

6. Moldovan, Z. and Alexandrescu, L. (2002). 2Mercaptobenz-imidazole used as antioxidant in polymeric materials. Acta Chim. Solv. 49:909-916

7. Pintilie, O., Profire L., Sunel.V., Popa, M. and Pui, A. (2007). Synthesis and antimicrobial activity of some new 1,3,4thiadiazole and 1,2,4-triazole compounds having a D,LMethioine moiety. Molecules, 12:103-113.

8. Al-Majidi, S.M.H. and AlMessri, Z.A.K. (2007). Synthesis of some new substituted 1,2,4-triazole and 1,3,4-thiadiazole and study of their activities on some strains of bacteria. Journal of AlNahrain University. 10:30-37.

9. Jin, J., Zhang, L., Chen, X., Zhang, $A$. and Zhang, $H$. (2007). Synthesis and biological activities of 6-aryl-3-(3hydroxy-propyl)-7-H-1,2,4-

triazolo $\quad[3,4-\mathrm{b}] \quad[1,3,4]$ thiadiazines. Molecules, 12:297303.

10. Koj, N., (1962), "Infrared abstraction Spectroscopy", Nankodo Company Limited, Tokyo.

11. Halasa, A.F. and Smith, G.E.P. (1971). Study of the Michael and Manich reactions with benzothiazole-2-thiol. J. Org. Chem. 36:636-641.

12. Hoggarth, F. (1952). J. Chem. Soc., 4811 .

13. Jack, R.R. and Ned, D.H. (1967), J. Heterocyclic Chem., 13:925.

14. Shriner, R.L., Fuson, R.C., Cartin, D.Y. and Morril, T.C. (1980). "The systematic Identification of Organic Compounds", $8^{\text {th }}$ ed., John Wiley and Sons, New York. 
15. Kuo, W., Wu, M., Chin, C. and Yeh, M. (2001). "The reaction studies of $\alpha$-chloroformylaryl hydrazines with thiols, thioureas and $\alpha$-cyclodiketones. Journal of the Chinese Chemical Society.

\title{
تحضير بعض مركبات 1, 2, 4- ترايزول الجديدة المشتقة من 2- مركبتوبنز اميدازول
}

\author{
زينب عبل الزهرة خضير المصري* \\ * قسم الكيمباء , كلبة العلوم , جامعة بغداد
}

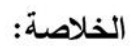

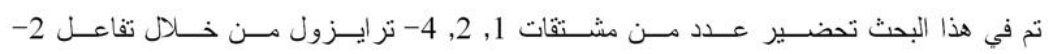

مركبتوبنز اميدازول مع اثثل كلورواستيت ليعطي اثيل ( بنز اميدازول- 2- ثايو ) استيت [ 1 ] ] , ثم تحويل الاستر الناتج الى مشتق الهيدر ازيد [ 2 [ الذي يتفاعل مع كل من الفنيل ايزوسيانات او الفنيل ايزوثايوسيانات

ليعقبها غلق حلقي في وسط قاعدي ليعطي المركبين 3- [( بنز اميدازول - 2 - ثايو ) مثيل ] - 4 - 4 - فنيل -

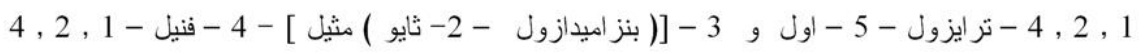
- تر ايزول - 5 - ثايول على التو الي -

كما ان تفاعل مشتق الهيدر از ايد [ 2 [ ] مع ثاني كبريتيد الكربون و هيدروكسيد البوتاسيوم ليعطي ملح

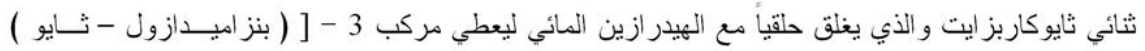

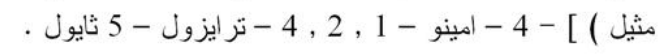

كدلك حضرت قو اعد شيف جديدة من تفاعل مشتق الهيدر از ايد [ 2 ] ] مــع الديهايــدات اروماتيــة

مختلفة .

شخصت المركبات المحضرة بــالطر ائق الطيفيـة [ U.V , FTIR ] وتعيـين بعـض خو اصــهـا 